O. Maistrenko ${ }^{1}$, A. Shcherba ${ }^{2}$, V. Yunda ${ }^{2}$, O. Karavanov ${ }^{2}$

${ }^{1}$ National Defense University of Ukraine named after Ivan Cherniakhovskyi, Kyiv

${ }^{2}$ Hetman Petro Sahaidachnyi National Army Academy, Lviv

\title{
USE OF LOTKA-VOLTERRA DIFFERENTIAL EQUATIONS FOR THE CREATION OF THE MODEL OF COMBAT USE OF MILITARY FORMATION IN THE MUTUAL FIRE CONDITIONS
}

The analysis of armed conflicts of recent decades suggests that the quantitative advantage in forces and means does not always ensure the successful completion of combat missions. Quite often, the organization of military formations combat use and enemy fire demage comes to the fore from the whole set of factors.

The article considers the possibility of using Lotka-Voltair differential equations in creating a model of combat use of military formations in terms of fire interaction.

These equations are widely used in the study of population growth dynamics of biological species under conditions of competition (when both parties are predators). The main hypotheses when using the above equations include the following: the supplies needed for growth are either available in unlimited quantities, or their income is strictly regulated over time; species harm each other, and per unit time the number of losses is always proportional to the probability of encountering individuals of these two species.

The application of the Lotka-Voltair equations allows to determine the dynamics of changes in the level of military formation capabilities in the conditions of mutual fire influence of the parties and to determine the critical level of capabilities, and further, on the basis of this information to provide recommendations for changing certain constants.

Key words: military formation capabilities, fire for effect of the enemy, differential equations of LotkaVolterra.

\section{Introduction}

The rapid development of military skills has recently led to the search for more detailed and precise ways of describing the processes that take place during the combat conflicts. The results of multifactorial analysis of recent armed conflicts [1-2] indicate that quantitative superiority in forces and means does not guarantee the successful realization of combat missions. At the forefront of the whole set of factors is the organization of military use of military formations and fire for effect of the enemy [2]. The essential basis of the organization of combat use is to determine the totality of capabilities of military formation and ways of their maximum realization [3]. However, existing approaches to determining the capabilities of military formations are based on the static determination of the quantitaty of forces and means, taking into account through the appropriate coefficients of their qualitative characteristics. However, qualitative characteristics of the same military formation will change during combat use and will vary depending on conditions. In other words, existing approaches do not take into account the dynamics of changing the capabilities of military formation in the process of combat use.
Thus, in practice, the organization of the military use of military formations and the fire for effect of the enemy, there was an urgent need to find such ways to determine the military formation capabilities that would take into account the dynamics (intensity) of their changes in the process of combat use and fire for effect of the enemy.

\section{Analysis of recent researches and publications}

The results of research analysis on the determination of the capabilities of military formation in combat use and fire for effect of the enemy [4-6] indicate some directions for the development of these research.

First, it is the search for universal coefficients that characterize the qualitative component of a specific model of armaments and military equipment as part of the capabilities of military formation [4-5]. However, with the appearance of a relatively large number of types of armaments and military equipment and military formations, as well as new methods of their use, the number of combinations of their unification in formation has increased significantly, which has led to a significant increase in the range of conditions for the military use of military formations and fire for effect of the enemy. In this case, the definition of sustainable coefficient that characterizes a qualitative characteristic will lead to significant mistakes. 
Secondly, it is the searching of certain functional correlations in military formation and their reaction to changing conditions [6]. These approaches, in the authors opinion, are more perspective in view of need to take into account the dynamics of changes in the capabilities of military formation under conditions of fire interference. However, these approaches are not sufficiently worked out for their practical use. The main problem issues ia non-availability of such model of military formations use under conditions of fire interference, which will allow practically to determine the dynamics of change of capabilities with given accuracy (considering the interference).

Of course, there is a certain set of models that are based on the intensity of changing certain characteristics of military formation. These models include those based on Osipov-Lanchester equation [7], Kolmogorov equations for fixed states [8], (medium dynamics), approaches of Queueing theory [9]. However, these models do not fully allow to take into account the dynamics of the mutual change in the capabilities of military formation under conditions of fire interaction and to determine the critical level of these capabilities (bifurcation point).

Thus, in determining the dynamics of the change of level of military formation capabilities under the conditions of fire interference, it became necessary to create such a model that would take into account the mutual change of indicated capabilities and would allow to determine their critical level (the point of bifurcation)

Of course, in other branches of science there are approaches to solving problems similar in terms of conditions. So, in the study of the dynamics of population growth of biological species, a model based on the system of differential equations of Lotka-Volterra [10] is widely used. These equations allow us to determine the dynamics of changes in the population of biological species, provided that they compete (when both sides are predators), as well as to determine the critical level of growth rates. Thus, in the opinion of the author, it is expedient to consider the possibility of using the above equations for conditions of combat use of military formations under mutual fire, as biological species with certain parameters of mutual influence.

\section{Main purpose of the article}

Thus, the purpose of the article is to justify the possibility of using the differential equations of LotkaVolterra to create a model of military formation military use under mutual fire conditions.

\section{Results and discussions}

The essence of the approaches of the Lotka-Voltaire is to describe the dynamics of the change of interacting populations of biological species by differential equations of the first order [10]. The main hypotheses when using the equations are as follows: supplies required for growth or are in an unlimited number, or their receipt is tightly regulated over time; biological species damage each other, and in unit time, the amount of losses is always proportional to the probability of meeting the individuals of these two species, that is, multiplying the number of one species by the number of another [10].

These hypotheses can be applied to the process of military use of military formation under the mutual fire conditions. Thus, supplies, for conditions of military use of military formation, it is possible understand as ammunition, as their presence directly influences the quantitative change of the enemy, but as a consequence of the intensity of its tasks. Concerning the hypothesis that biological species inflicts damage to each other, and in unit time, the amount of losses is always proportional to the probability of meeting the individuals of these two species, it can be noted that the intensity of the loss in relation to the military use of military formations is always proportional to the probability (intensity) of detecting enemy objects. The term corresponds fully to the "principle of collisions" [10], when the rate of interaction is proportional to the multiplication of the density of the interacting components.

In general terms and in accordance with Volterra's hypothesis, the dynamics of interaction between two sides can be described by the equations [10]:

$$
\left.\begin{array}{l}
\frac{d N_{1}}{d t}=a_{1} N_{1}-b_{12} N_{1} N_{2}-c_{1} N_{1}^{2} ; \\
\frac{d N_{2}}{d t}=a_{2} N_{2}-b_{21} N_{1} N_{2}-c_{2} N_{2}^{2} \cdot
\end{array}\right\},
$$

where $N_{1}, N_{2}$ - parameters of interacting species (sides) to be investigated;

$a_{1}, a_{2}-$ constants of the own parameter growth rate;

$c_{1}, c_{2}-$ constants of self-limitation parameter (intraspecific competition);

$b_{12}, b_{21}-$ the constants of species interaction.

This model, at first sight, would be appropriate to use to determine the dynamics of change in the number of parties. In this case, the rate constants of growth $a_{1}, a_{2}$ will degenerate or characterize the rate of replenishment of the number. Concerning the constants of self-restraint $c_{1}, c_{2}$, it can be noted that they characterize a certain inconsistency in actions that will be expressed due to lower level of implementation of 
the capabilities of the party. The interaction constants $b_{12}, \quad b_{21}$ can be indirectly determined by the intensity of the tasks, but it will not always be directly dependent on the number of the parties. Therefore, the adequacy of such a constant is questionable.

Thus, considering the significant heterogeneity of the components of military formations, and the specifics of the interaction of the parties, it is more appropriate, in the author's opinion, to use the parameter for research the number of means that perform tasks $\left(N_{1}, N_{2}\right)$ [11]. Under the tasks in the study it is proposed to understand - the typical tasks inherent in a certain functional component of the military formation, which directly affect the enemy functioning. Taking into account the above, it can be noted that the constants of the own growth rate of the parameter $\left(a_{1}, a_{2}\right)$ will be characterized by the intensity of the tasks.

$$
\left.\begin{array}{l}
a_{1}=\lambda_{1}^{(v)} ; \\
a_{2}=\lambda_{2}^{(v)}
\end{array}\right\},
$$

where $\lambda_{1}^{(v)}, \lambda_{2}^{(v)}$ - intensity of performing tasks by one and other side.

Constants of self-restraint $c_{1}, c_{2}$ are proposed to be accepted as characterizing the work of the internal elements of the parties regarding the transfer of intelligence information to means of fire influence [12]. The constants of self-restraint are proposed to express due to the intensity of the intelligence and the intensity of the transmission of the data received.

$$
\left.\begin{array}{l}
c_{1}=1-\frac{\lambda_{1}^{(p)}}{\lambda_{1}^{(r)}} ; \\
c_{2}=1-\frac{\lambda_{2}^{(p)}}{\lambda_{2}^{(r)}}
\end{array}\right\} \text { if } \quad \lambda^{(p)} \geq \lambda^{(r)},
$$

where $\lambda_{1}^{(p)}, \lambda_{2}^{(p)}$ - intensity decision-making by one and other side;

$\lambda_{1}^{(r)}, \lambda_{2}^{(r)}$ - intensity of detecting enemy objects by one and other side.

Regarding the intensity of the intelligence, it is possible to assume that the acquisition of this indicator of zero value indicates a complete lack of opportunity to obtain information about the enemy. In this case, the intensity of the tasks will also be zero and, accordingly, there will be no need to further explore such a military formation. After all, the speed of its destruction will depend on the characteristics of the military formation of the enemy.

In the accepted conditions, the interaction constant $b_{12}, b_{21}$ can be determined by the intensity of the tasks performed by the opponent given to the indicator of the stability of the functioning of our military formation.

$$
\left.\begin{array}{l}
b_{12}=1-\frac{\lambda_{1}^{(v)}}{\lambda_{2}^{(v)}} ; \\
b_{21}=1-\frac{\lambda_{2}^{(v)}}{\lambda_{1}^{(v)}} .
\end{array}\right\},
$$

where $\lambda_{1}^{(v)}, \lambda_{2}^{(v)},-$ intensity of performing tasks by one and other side.

Under the indicator of the stability of the functioning of the military formation is proposed to take the inverse of the intensity of failure to perform tasks $\frac{1}{\lambda^{(v)}}$. Under the failures within this research, it is proposed to understand the impossibility of performing a task under the influence of internal and external factors [13]. It should be noted that the intensity of failures during the performance of tasks, as an indicator that characterizes the stability of the functioning of the military formation, can not take zero significance, just as military formation with an absolute index of stability can exist only under ideal conditions. Of course, the intensity of failures when performing tasks, for the study may reach the value close to zero, however, can not degenerate.

Thus, taking into account expressions (2), (3), (4) the system of equations (1) will look like

$$
\left.\begin{array}{c}
\frac{d N_{1}}{d t}=\lambda_{1}^{(83)}{ }_{1} N_{1}-\frac{\lambda_{1}^{(63)}}{\lambda_{2}^{(8)}} N_{1} N_{2}-\left(1-\frac{\lambda_{1}^{(n)}}{\lambda_{1}^{(p)}}\right) N_{1}^{2} \\
\frac{d N_{2}}{d t}=\lambda_{2}^{(63)} N_{2}-\frac{\lambda_{2}^{(63)}}{\lambda_{1}^{(8)}} N_{1} N_{2}-\left(1-\frac{\lambda_{2}^{(n)}}{\lambda_{2}^{(p)}}\right) N_{2}^{2}
\end{array}\right\}
$$

Using a differential approach to the solution of differential equations (5) can be written in the following form

$$
\left.\begin{array}{l}
N_{1}^{(i+1)}=N_{1}^{(i)}+\Delta t\left(\left(\lambda_{1}^{(83)}-\frac{\lambda_{2}^{(83)}}{\lambda_{1}^{(8)}} N_{2}-\left(1-\frac{\lambda_{1}^{(n)}}{\lambda_{1}^{(p)}}\right) N_{1}\right) N_{1}\right) ; \\
N_{2}^{(i+1)}=N_{2}^{(i)}+\Delta t\left(\left(\lambda_{2}^{(83)}-\frac{\lambda_{1}^{(83)}}{\lambda_{2}^{(8)}} N_{1}-\left(1-\frac{\lambda_{2}^{(n)}}{\lambda_{2}^{(p)}}\right) N_{2}\right) N_{2}\right) .
\end{array}\right\}
$$


For further research it is suggested to accept certain input data and to analyze the results of modeling. So for the input data $N_{1}=3, N_{2}=1, a_{1}=4, a_{2}=2$, $c_{1}=0,1, c_{2}=0,1, b_{12}=2,5, b_{21}=1, \Delta t=0,1$ the schedule of the proceeding of the function will have the following form (Figure 1)

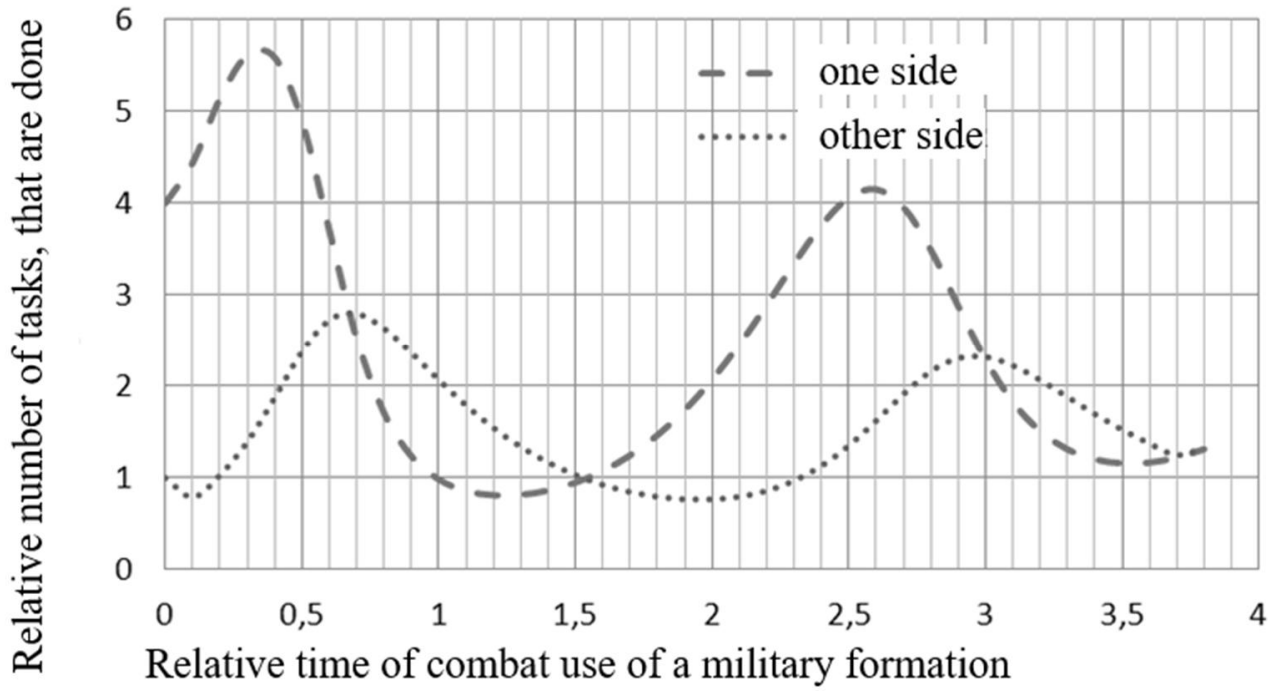

Fig. 1.The schedule of the proceeding of the function

The analysis of Proceeding of the indicators functions of capabilities implementation of military formations of the sides indicates that, given the "principle of collisions", it will have a wave-like form. It is clear that the more one side performs the tasks, the more the other side detects the firearms and, accordingly, implements a large number of tasks and vice versa. This is possible in the case when the parties have enough intelligence strength. In addition, it should be noted that indicators of the implementation of the capabilities of the military formations of the sides in the identified model may acquire negative meanings that can not be explained in the physical sense. However, in view of the mathematical interpretation, it can be argued that the interaction rates are strongly influenced by the sign. Indeed, the results of interaction in the first place is the intensity of failures is reduced to the intensity of the task of the enemy, in the case when the failure is caused only by the task of the opposing side. In this case, the interaction constants will be in the range from 0 to 1 .

In addition, the number of tasks performed by the sides $\left(N_{1}, N_{2}\right)$ is a rather ambiguous parameter, which, in the case of not being related to the executor (tasks), can acquire values from $+\infty$ to $-\infty$, which is physically incorrect. Therefore, it is proposed to accept for the parameter $N_{1}, N_{2}$, within the limits of the research, the ratio of uniform types of military elements that are ready to perform tasks to the total number of such elements.

Also, it is necessary to note several stationary solutions of a given system of differential equations [10]. So, $N_{1}=0, N_{2}=0$ with all the parameters, the solution of the system can be described as an unstable node, that is, it is impossible to predict the further functions proceeding. If $N_{1}=0, N_{2}=a_{2} / c_{2}$ if $a_{1}>b_{12} / c_{2}$ that solution of the system of equations is a saddle if $a_{1}<b_{12} / c_{2}-$ a stable node. These conditions mean that one of the sides will be destroyed if its own intensity of the tasks is less than a certain critical value. This decision takes place and at $N_{2}=0$, $N_{1}=a_{1} / c_{1}$. The next decision $N_{1}=\frac{a_{1} c_{2}-a_{2} b_{12}}{c_{1} c_{2}-b_{12} b_{21}}$, $N_{2}=\frac{c_{1} b_{12}-a_{1} b_{21}}{c_{1} c_{2}-b_{12} b_{21}}$ characterizes roughly the ability levels of the parties and is a stable node when the condition is fulfilled $\frac{a_{1} b_{12}}{c_{2}}<a_{1}<\frac{c_{1} a_{2}}{b_{21}}$.

Of course, this model can not be without the appropriate "calibration" taking into account the actual processes that affect the execution of tasks. However, when using the model, even in this form, one can predict the general proceeding of the functions of indicators of the implementation of the capabilities of the military formations of the sides for the given conditions, and provide the necessary recommendations for increasing the degree of implementation of capabilities.

\section{Conclusions and further researches directions}

Thus, the use of differential Lotka-Volterra equations in creating a model of military use of military formation under mutual fire conditions will determine the dynamics of changes in the level of capabilities of military formation in the conditions of mutual fire impact of the 
sides and accordingly determine the critical level of abilities (the point of bifurcation). In the future, based on the information on the dynamics of changes in the level of capabilities of the military formation and their critical level, it is possible to provide recommendations for changing these or other constants or, if possible, the initial value of the parameter being studied.

Further research is proposed to be devoted to refining the components of the identified model, in particular, the constants and parameters under research.

\section{References}

1. Repilo YU.YE. (2001), "Vohneve urazhennya protyvnyka $i$ boyove zabezpechennya pry boyovykh diyakh u lokal'nymu konflikti v umovakh hirs'ko-lisystoyi mistsevosti." [Enemy fire defeat and combat support during fighting in local conflict under mountainous and forest terrain conditions]: Tutorial, NAOU, Kyiv, 56 p. [in Ukrainian].

2. Maystrenko O.V. (2016), "Udoskonalennya zmistu pryntsypiv zastosuvannya raketnykh viys'k $i$ artylerii pid chas vohnevoho urazhennya protyvnyka." [The content of principles improving of missile troops and artillery using during enemy fire] Collection of scientific works of the Center for Military and Strategic Studies of the Ivan Chernoyakhovsky National University of Defense of Ukraine. Kyiv, 2016. Issue № 3 (58). pp. 75-80. DOI: https://doi.org/10.33099/2304-2745/2016-358/75-80. (Accessed 29 May 2020). [in Ukrainian].

3. Adamchuk M.M, Norchuk YU.V., Luhovs'kyy I.S. and Myn'ko O.V. (2019), " Analiz sposobiv zastosuvannya artyleriyi $v$ zbroynykh konfliktakh." [Ways analysis of artillery use in armed conflicts] Collection of scientific works. Odessa, 2019. Issue № 1 (11). pp. 155-163. DOI: https://doi.org/ 10.37129/ 2313-7509.2019.11.155-163 (Accessed 16 June 2020). [in Ukrainian].

4. Shulgin V.E., and Fesenko Yu.N. (1997), " O kriteriyakh ognevogo porazheniya ob'yektov $i$ gruppirovok voysk $v$ operatsii." [On the criteria for fire destruction of objects and groupings of troops in operations]. Military thought. Moscow, 1997. Issue No 6. pp. 58-64.

URL: http://militaryarticle.ru/voennaya-mysl/1997vm/9656-o-kriterijah-ognevogo-porazhenija-obektov-i. (Accessed 26 May 2020). [in Ukrainian].

5. Kalinovskiy O.N. (1996), "Ob otsenke ognevykh vozmozhnostey voysk $v$ operatsii." [On the assessment of fire capabilities of troops in operations]. Military thought. Moscow, 1996. Issue No 5. pp. 52-56. URL: http://militaryarticle.ru/ voennaya-mysl/1996-vm/8805-ob-ocenke-ognevyh-vozmozhnostejvojsk-v-operacii . (Accessed 26 May 2020). [in Ukrainian].

6. Trotsenko K.A. (2008), "O realizatsii boyevykh vozmozhnostey takticheskoy gruppirovki voysk." [On the implementation of combat capabilities of the tactical grouping of troops]. Military Thought. Moscow, 2008. Issue No 6. pp. 70-75. URL:http://militaryarticle.ru/voennaya-mysl/2008vm/10159-o-realizacii-boevyh-vozmozhnostej-takticheskoj. (Accessed 27 May 2020). [in Ukrainian].

7. Buyanov B.B., Lubkov N.V. and Polyak G.L. (2007), "Matematicheskaya model' dlitel'nogo vooruzhennogo konflikta" [Mathematical model of long-term armed conflict]. Management problems. Moscow, 2007. Issue No 5. pp. 48-51. URL: https://cyberleninka.ru/article/n/matematicheskaya-modeldlitelnogo-vooruzhennogo-konflikta/viewer. (Accessed 26 May 2020). [in Ukrainian].

8. Polyak G.L. (2011), "Matematicheskaya model' ekonomicheskikh posledstviy vooruzhennogo protivostoyaniya neravnykh po sile protivnikov." [A mathematical model of the economic consequences of armed confrontation with unequal opponents]. Mathematical and instrumental methods of economics. Tambov, 2011. Issue No 12 (85). pp. 381-386. URL: http://ecsocman.hse.ru/data/2012/10/03/1251351717/ 81.pdf. (Accessed 27 May 2020). [in Ukrainian].

9. Polenin V.I. (2004), "Primeneniye veroyatnostnykh modeley pri planirovanii operatsiy " [Application of probabilistic models in operations planning]. Military Thought. Moscow. 2004. Issue No 3. pp. 54-55. URL: http:// militaryarticle.ru/voennaya-mysl/2004-vm/9430-primenenieverojatnostnyh-modelej-pri-planirovanii. (Accessed 28 May 2020). [in Ukrainian].

10. Bondarchuk S.S. and Perevozkin V.P. (2014), "Matematicheskoye modelirovaniye v populyatsionnoy ekologii" [Mathematical modeling in population ecology]: Tutorial, TGPU, Tomsk 224 p. [in Ukrainian].

11. Maistrenko O.V., Karavanov O.A., Stegura S.I., Davidovsky L.S., and Spasun V.I.(2020) "Doslidzhennya funktsionuvannya rozviduval'no-vohnevoyi systemy shlyakhom stvorennya modeli vohnevoho urazhennya protyvnyka." [Reconnaissance fire system functioning research by creating a model of enemy fire destruction.]. Weapons and military equipment. Kyiv, 2020.. Issue № 2 (26). pp. 50-58. [in Ukrainian]. DOI: https://doi.org/10.34169/2414-0651. 2020.2 (26).50-58.

12 Uhm, H., Lee, Y..(2019), "A Heuristic Algorithm for Weapon Target Assignment and Scheduling." [ A Heuristic Algorithm for Weapon Target Assignment and Scheduling]. Military Operations Research. 2019. Issue № 24(4). pp. 5362. DOI:http://doi.org/10.5711/1082598324453. (Accessed 28 May 2020). [in Ukrainian].

13. Maistrenko O.V., Repilo YU.YE. and Demidko D.L. (2015), "Vyznachennya oblasti dotsil'nykh znachen' dlya pokaznykiv tochnosti ta raptovosti vohnyu artylerii (udariv raket)." [Determination of appropriate values range for indicators of accuracy and suddenness of artillery fire (missile strikes)]. Modern information technologies in the field of security and defense. Kyiv, 2015. Issue № 1 (22). pp. 79-83. URL: http://nbuv.gov.ua/UJRN/sitsbo_2015_1_15. (Accessed 28 May 2020). [in Ukrainian].

\section{Список літератури}

1. Репіло Ю. С. Вогневе ураження противника $і$ бойове забезпечення при бойових діях у локальному конфлікті в умовах гірсько-лісистої місиевості : навчальний посібник. Киї: НАOУ, 2001. 56 c.

2. Майстренко О. В. Удосконалення змісту принципів застосування ракетних військ $i$ артилерії під час вогневого ураження противника. Збірник наукових прачь Центру воєнно-стратегічних досліджень Національного університету оборони України імені Івана Черняховського. Київ. 2016. № 3(58). C. 75-80. DOI: https://doi.org/10.33099/23042745/2016-3-58/75-80. (дата звернення: 29.05.2020). 
3. Адамчук М. М, Норчук Ю. В., Луговський I. С., Минько О.В. Аналіз способів застосування артилерії в збройних конфліктах. Збірник наукових праць. Одеса. 2019. № 1 (11). C. 155-163. DOI: https://doi.org/10.37129/ 2313-7509.2019.11.155-163 . (дата звернення: 16.06.2020).

4. Шульгин В. Е., Фесенко Ю. Н. О критериях огневого поражения объектов и группировок войск в операции. Военная мыслль. Москва.1997. № 6. С. 58 - 64. URL: http:// militaryarticle.ru/voennaya-mysl/1997-vm/9656-o-kriterijahognevogo-porazhenija-obektov-i. (дата звернення: 26.05.2020).

5. Калиновский О.Н. Об оченке огневых возможностей войск в операчии. Военная мысль. Москва. 1996. № 5. C. 52-56. URL: http://militaryarticle.ru/voennaya-mysl/ 1996-vm/8805-ob-ocenke-ognevyh-vozmozhnostej-vojsk-vорегасіi. (дата звернення: 26.05.2020).

6. Троценко К. А. О реализации боевых возможностей тактической группировки войск. Военная мыслль. Москва. 2008. № 6. C. 70 - 75. URL: http://militaryarticle.ru/ voennayamysl/2008-vm/10159-o-realizacii-boevyh-vozmozhnostejtakticheskoj. (дата звернення: 27.05.2020).

7. Буянов Б. Б., Лубков Н. В., Поляк Г. Л. Математическая модель длительного вооруженного конфликта. Проблемы управления. Москва. 2007. №5. С.48-51. URL: https://cyberleninka.ru/article/n/matematicheskaya-modeldlitelnogo-vooruzhennogo-konflikta/viewer. (дата звернення. 26.05.2020).

8. Поляк Г. Л. Математическая модель экономических последствий вооруженного противостояния неравных по силе противников. Математические и инструментальные методы экономики. Тамбов. 2011. № 12(85). С. 381 - 386. URL: http://ecsocman.hse.ru/data/2012/10/03/1251351717/ 81.pdf. (дата звернення: 27.05.2020).

9. Поленин В.И. Применение вероятностных моделей при планировании операций. Военная мысль. Москва. 2004. № 3. C. 54-55. URL: http://militaryarticle.ru/voennaya-mysl/ 2004-vm/9430-primenenie-verojatnostnyh-modelej-priplanirovanii. (дата звернення: 28.05.2020).

10. Бондарчук С. С., Перевозкин В. П. Математическое моделирование в популяиионной экологии: учебное пособие. Томск: ТГПУ, 2014. 224 c.

11. Майстренко О. В., Караванов О. А., Стегура С. I., Давидовський Л. С., Спасун В.І. Дослідження функиіонування розвідувально-вогневої системи шляхом створення моделі вогневого ураження противника. Озброєння та військова техніка. Київ. 2020. № 2(26). С. 50-58. DOI: https://doi.org/10.34169/2414-0651.2020. 2(26).50-58.

12. Uhm, H., Lee, Y. A Heuristic Algorithm for Weapon Target Assignment and Scheduling. Military Operations Research. 2019. № 24(4), C. 53-62. DOI: http://doi.org/10.5711/1082598324453. (дата звернення: 28.05.2020).

13. Майстренко О. В., Репіло Ю. Є., Демидко Д.Л. Визначення області доцільних значень для показників точності та раптовості вогню артилерії (ударів ракет). Сучасні інформачійні технології у сфері безпеки та оборони. Kuïв. 2015. № 1(22). C. 79-83. URL: http://nbuv.gov.ua/UJRN/sitsbo_2015_1_15. (дата звернення: 28.05.2020).

\section{Використання диференційних рівнянь Лотки-Вольтера для створення моделі бойового застосування військового формування в умовах вогневого взасмовпливу}

\section{О.В. Майстренко, А.А. Щерба, В.А. Юнда, О.А. Караванов}

Проведений аналіз збройних конфліктів останніх десятиріч дозволяе стверджувати, щуо кількісна перевага в силах $i$ засобах не завжди забезпечує успішне виконання бойових завдань. Досить часто з усієї сукупності чинників на перший план виступає організачія бойового застосування військових формувань та вогневого уражсеня противника.

Результати аналізу досліджень, які проводились щодо визначення спроможностей військового формування в процесі бойового застосування та вогневого ураження противника (ВУП), показують, що зазначені спроможності базуються на статичному визначенні кількісного складу сил і засобів сторін з урахуванням їх якісних характеристик через відповідні коефіцієнти. Такий підхід не враховує динаміку зміни спроможсностей військового формування в процесі бойового застосування. На думку авторів, більш перспективними є пошук функиіональних взаємозв'язків у військовому формуванні та їх реакиія на зміну умов. Однак, зазначені питання є недостатньо дослідженими, щуо не повною мірою дозволяє врахувати динаміку взаємної зміни спроможностей військового формування в умовах вогневого взаємовпливу та визначити критичний рівень означених спроможностей (точку біфуркаиії).

У статті розглядається можливість використання диферениійних рівнянь Лотки-Вольтера при створенні моделі бойового застосування військового формування в умовах вогневого взаємовпливу.

Дані рівняння широко застосовуються при дослідженні динаміки росту популяиії біологічних видів за умови їх конкуренції (коли обидві сторони є хижсаками). До основних гіпотез при використанні вищезазначених рівнянь відносяться наступні: припаси, необхідні для росту, або є в необмеженій кількості, або їх надходження з часом жорстко регламентоване; біологічні види завдають збитків один одному, причому в одиницю часу кількість втрат завжди пропориійна вірогідності зустрічі особин ичих двох видів.

Застосування рівнянь Лотки-Вольтера дозволяе визначити динаміку зміни рівня спроможностей військового формування в умовах взаємного вогневого впливу сторін та відповідно визначити критичний рівень спроможностей, а 8 подальшому, на підставі цієї інформації, надати рекомендації щодо зміни тих чи інших констант.

Ключові слова: спроможності військового формування, вогневе ураження противника, диференційні рівняння Лотки-Вольтера. 


\section{Использование дифференциальных уравнений Лотки-Вольтера для создания модели боевого применения} военных формирований в условиях огневого взаимовлияния

\section{А.В. Майстренко, А.А. Щерба, В.А. Юнда, А.А. Караванов}

Проведенный анализ вооруженных конфликтов последних десятилетий позволяет утверждать, что преобладание 6 силах и средствах не всегда обеспечивает успешное выполнение боевых задач. Довольно часто из всей совокупности факторов на первый план выходит организация боевого применения воинских формирований и огневого поражения противника.

Результаты анализа исследований, проводимых по определению возможностей воинского формирования в процессе боевого применения и огневого поражения противника, показывают, что указанные возможсноти базируются на статическом определении количественного состава сил и средств сторон с учетом их качественных характеристик через соответствующие коэффициенты. Такой подход не учитывает динамику изменения возможностей воинского формирования в процессе боевого применения. По мнению авторов, более перспективными являются поиск функцииональных взаимосвязей в воинском формировании и их реакиия на изменение условий. Однако, указанные вопросы являються недостаточно исследованными, что не в полной мере позволяет учесть динамику взаимного изменения возможностей воинского формирования в условиях огневого взаимовлияния и определить критический уровень указанных возможностей (точку бифуркачии).

В данной статье рассматривается возможность использования дифференциальных уравнений Лотки-Вольтера при создании модели боевого применения воинского формирования в условиях огневого взаимовлияния.

Данные уравнения широко применяются при исследовании динамики роста популяции биологических видов при условии их конкуренции (когда обе стороны являются хищниками). К основным гипотезам при использовании вышеуказанных уравнений относятся следующие: припасы, необходимые для роста, или есть в неограниченном количестве, или их поступление со временем жестко регламентировано; биологические виды наносят ущерб друг другу, причем в единииу времени количество потерь всегда пропориионально вероятности встречи особей этих двух видов.

Применение уравнений Лотки-Вольтера позволяет определить динамику изменения уровня возможностей воинского формирования в условиях взаимного огневого воздействия сторон и, соответственно, определить критический уровень возможностей, а в дальнейшем, на основании этой информации, дать рекомендации по изменению тех или иных констант.

Ключевые слова: возможности воинского формирования, огневое поражение противника, дифференциальные уравнения Лотки-Вольтера. 